\title{
Zakat Fitrah kepada Dukun Bayi dalam Perspektif Hukum Islam
}

\author{
Moh. Taufik Hidayat, Tri Handayani, Ubbadul Adzkiya' \\ Universitas Wahid Hasyim Semarang \\ h.mohamadtaufik@gmail.com, trihandayani1964@gmail.com, adzkiya@unwahas.ac.id
}

\begin{abstract}
The implementation of zakat fitrah is generally left to the amil zakat, so that the practice of zakat goes well according to the guidance of Islamic law, meaning that muzakki pays zakat really mustahik also receive according to conditions as a group that is entitled to receive zakat fitrah. The zakat fitrah manager in Lipursari Village, residents who have children under the age of 2 years, issue zakat directly to their dukun and not through the zakat fitrah manager (Amil) at the local mosque.

The type of research carried out by researchers is field research or field research conducted in the village of Lipursari. The author uses data collection methods, namely interviews. Sources of data in this study are sourced from primary data and secondary data sources. Then the writer analyzed using descriptive analysis method using a qualitative approach. The results showed: The practice of Zakat Fitrah to traditional birth attendants in the village of Lipursari was not in accordance with the Zakat Law no. 23 of 2011. However, the distribution of zakat fitrah is allowed, it is because one of the customs that is running or carried out by the local community has existed for a long time and has been passed down from generation to generation. The traditional birth attendant in the village of Lipursari is included in the group of people who are entitled to receive zakat fitrah. This is because the people in Lipursasi village are mostly farmers, so the traditional birth attendants do not burden the local community to give large amounts of wages, because basically the traditional birth attendant has the principle of ta'awun or help for the common welfare.
\end{abstract}

Keyword: Islamic Law, Distribution, Zakat Fitrah, Old-midwife (Dukun Bayi)

Abstrak

Pelaksanaan zakat fitrah umumnya diserahkan kepada amil zakat, sehingga praktik zakat berjalan dengan baik sesuai tuntunan syari'at Islam, artinya muzakki mengeluarkan zakatnya dengan benar mustahik juga menerima sesuai kondisi sebagai golongan yang berhak menerima zakat fitrah. Pengelola zakat fitrah di Desa Lipursari penduduk yang mempunyai anak dibawah umur 2 tahun mengeluarkan zakat secara langsung kepada dukun bayinya dan tidak melalui pengelola zakat fitrah (Amil) di masjid setempat.

Jenis penelitian yang dilakukan peneliti adalah penelitian lapangan atau field research yang dilakukan di Desa Lipursari. Penulis menggunakan metode pengumpulan data yaitu wawancara. Sumber data dalam penelitian ini yaitu bersumber dari data primer dan sumber data sekunder. Kemudian penulis menganalisis dengan menggunakan metode deskriptif analisis dengan menggunakan pendekatan kualitatif. Hasil penelitian menunjukkan: Praktik Zakat Fitrah kepada dukun bayi di desa Lipursari belum sesuai dengan Undang-undang zakat No. 23 th 2011. Namun pendistribusian zakat fitrah diperbolehkan, hal itu dikarenakan salah satu adat istiadat yang berjalan atau dilakukan oleh masyarakat setempat sudah ada sejak dulu dan turun temurun. Dukun bayi di desa Lipursari termasuk dalam golongan orang yang berhak mendapatkan zakat fitrah. Hal ini dikarenakan masyarakat di desa Lipursasi sebagian besar sebagai petani, sehingga dukun bayi tidak memberatkan masyarakat setempat untuk memberi upah dalam jumlah besar, karena pada dasarnya dukun bayi berprinsip ta'awun atau tolong menolong untuk kesejahteraan bersama.

Keyword: Hukum Islam, Pendistribusian, Zakat Fitrah, Dukun Bayi 


\section{Pendahuluan}

Islam adalah agama yang selalu memberikan rahmat setiap manusia yang ada di dunia dan di akhirat nanti. Islam juga sangat erat memegang tingginya prinsip solidaritas yang hakiki, banyak sekali ajaran Islam yang menganjurkan bahkan mewajibkan pemeluknya untuk memegang prinsip yang mulia dan yang disyari'atkannya. Salah satunya adalah solidaritas, itu bisa dilihat dari konsep saling menyayangi, saling menghormati, saling membantu, sedekah, tolong menolong, zakat dan lainnya. ${ }^{1}$ Di antara bentuk bukti ibadah dalam Islam yang memiliki prinsip mulia ini dan mengancu pada dua dimensi yaitu dimensi vertikal (hablun min Allah) dan dimensi horizontal (hablun min al-nâs) yaitu zakat. Ibadah zakat apabila dilakukan dengan baik maka akan meningkatkan keimanan dan mensucikan jiwa kita dari sifat kikir, tamak, dengki, membangun masyarakat yang lemah, serta dapat mengembangkan dan memberkahkan harta yang dimilikinya. ${ }^{2}$

Hukum islam memandang harta mempunyai nilai yang strategis, karena ia merupakan alat dan sarana untuk memperoleh berbagai manfaat dan mencapai kesejahteraan hidup manusia sepanjang waktu. Hubungan manusia dengan harta sangatlah erat. Demikian eratnya hubungan tersebut, sehingga naluri manusia untuk memiliknya menjadi satu dengan naluri mempertahankan hidup manusia itu sendiri. ${ }^{3}$

Zakat merupakan ajaran Islam yang termasuk dalam ibadah māliyah ijtimā'iyyah (ibadah yang berkaitan dengan ekonomi dan masyarakat) yang mempunyai status dan peran penting dalam ajaran Islam. Seperti rukun Islam yang lain, ajaran zakat menyimpan beberapa dimensi yang kompleks meliputi nilai privat, publik, vertikal, horizontal, serta ukhrāwī dan duniawī. ${ }^{4}$ Dengan demikian, zakat dan pengelolaannya diperlukan dan mutlak untuk dilaksanakan. ${ }^{5}$ Zakat dibagi menjadi 2 yaitu zakat mal dan

1 Ubbadul Adzkiya', Etika Bisnis Nabi Muhammad SAW: Sejarah, Ajaran Dan Praktik (Penerbit Lawwana, 2021), https://books.google.co.id/books?id=M7sxEAAAQBAJ.

${ }^{2}$ M. Ali Hasan, Zakat Dan Infak: Salah Satu Solusi Mengatasi Problema Sosial Di Indonesia (Jakarta: Prenada Media, 2006), hlm. 18-23.

${ }^{3}$ Abdurrachman Qhadir, Zakat: Dalam Dimensi Mahdhah dan Sosial, Jakarta: PT. Raja Grafindo Persada, 2001. hlm. 1

${ }^{4}$ Hafidz Syuhud and Islamic Law, "Interrelation of Mind and Revelation: Analysis of the Thought of Ulama Mutakallimin in the Formation of Islamic Law Interelasi Akal Dan Wahyu: Analisis Pemikiran Ulama Mutakallimin Dalam Pembentukan Hukum Islam" 2, no. 1 (2021): 43-61, https://doi.org/10.24260/jil.v.

${ }^{5}$ Sudirman, Zakat Dalam Pusaran Moderenitas (Malang: UIN Malang Press, 2009), hlm. 1. 
zakat fitrah. Zakat maal adalah jenis zakat yang dikeluarkan individu maupun lembaga atas harta/penghasilan yang diperolehnya dengan syarat dan kententuan yang sudah ditetapkan. Sedangkan zakat fitrah sendiri adalah zakat wajib yang harus dikeluarkan setahun sekali yaitu saat bulan ramadhan sampai menjelang sholat idul fitri.

Salah satu hadist yang menjelaskan kewajiban zakat fitrah adalah sebagai berikut :

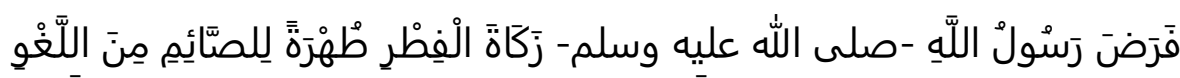

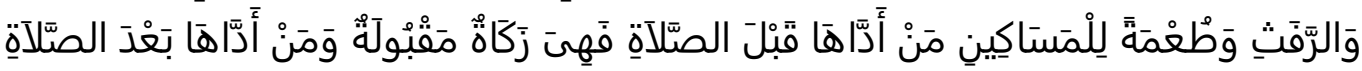
فَهِنَ صَدَقَةُ مِنَ الصَّدَقَاتِ

Artinya : Rasulullah shallallahu 'alaihi wa sallam mewajibkan zakat fitrah untuk menyucikan orang yang berpuasa dari bersenda gurau dan kata-kata keji, dan juga untuk memberi makan orang miskin. Barangsiapa yang menunaikannya sebelum shalat maka zakatnya diterima dan barangsiapa yang menunaikannya setelah shalat maka itu hanya dianggap sebagai sedekah di antara berbagai sedekah. ${ }^{6}$ (HR. Abu Daud, no. 1609; Ibnu Majah, no. 1827)

Permasalahan zakat juga tidak lepas dari masalah penerimaan zakat tersebut, sebagaimana kita ketahui bahwa Islam telah menentukan golongan-golongan yang berhak menerima zakat. Meskipun telah ada aturan secara jelas tentang zakat, akan tetapi dalam suatu lingkup masyarakat terkadang ada hal-hal yang sedikit berbeda, sebagaimana permasalahan zakat yang ada di Desa Lipursari Kecamatan Leksono Kabupaten Wonosobo. Sehingga di desa tersebut terdapat hal menarik untuk dikaji permasalahan zakat, baik dalam praktik pembayaran zakat maupun pendistribusiannya.

Pelaksanaan zakat fitrah biasanya diserahkan kepada amil zakat, sehingga praktik zakat berjalan dengan baik sesuai tuntunan syari'at Isla, artinya muzakki mengeluarkan zakatnya sesuai tata cara (hitungan dan kadar) yang benar dan mustahik juga menerima seuai kondisi dan kapasitasnya sebagai seorang atau golongan yang berhakn menerima zakat fitrah. Zakat fitrah yang dikumpulkn dari muzakki, langsung dibagikan kepada mustahik. Dengan demikian, manfaat zakat dapat dirasakan langsung oleh mustahik saat itu juga. Fenomen tersebut menunjukan bahwa kewajiban

\footnotetext{
${ }^{6}$ Darul Fikri.sch.id/mutiara-hadits-keutamaan-zakat-fitrah/. Diakses Selasa, 08 September 2020.
} 
menunaikan zakan bukanlah semata-mata bersifat amal karitatif (kedermawanan) belaka, namun zakat juga merupakan suatu kewajiban yang bersifat otoriatatif. ${ }^{7}$

Berkaitan dengan hal itu, pengelola zakat fitrah khususnya di Desa Lipursari Kecamatan Leksono Kabupaten Wonosobo penduduk yang mempunyai anak dibawah umur 2 tahun mengeluarkan zakat secara langsung kepada dukun bayinya dan tidak melalui pengelola zakat fitrah (Amil) di masjid setempat. Padahal di daerah tersebut sudah ada pengelola zakat yang dalam awal pembentukannya adalah bertujuan untuk mengelola zakat dari muzakki dengan harapan membantu muzakki menyalurkan zakatnya agar tepat sasaran. Fenomena semacam ini sudah menjadi kebiasaan penduduk Desa Lipursari Kecamatan Leksono Kabupaten Wonosobo. Hal ini terus berlangsung hingga saat ini.

Kebiasaan tersebut memberikan tanda tanya kepada penyusun tentang pengelola zakat, dimana pengelola zakat (Amil) yang sudah dibentu sedemikian rupa justru tidak berfungsi secara komprehensif (menyeluruh). Jika dalam penyerahan zakat oleh orang yang mengeluarkan zakat (muzakki) diberikan selain kepada pengelola zakat (Amil), yaitu dukun bayi berarti penyerahan zakat kepada pengelola zakat (Amil) ini tidak menjadikan wajib dan keberadaan Amil zakat khususnya juga tidaklah menjadi keharusan.

Masalah yang menyebabkan rendahnya realisasi potensi yang terjadi dalam pelaksanaan zakat disebabkan oleh kebiasaan masyarakat yang sudah berlaku dari nenek moyang. Berdasarkan realita tersebut maka peneliti tertarik untuk meneliti tentang bagaimana perspektif hukum islam melihat fenomena zakat yang dibayarkan kepada dukun bayi.

\section{Metodologi Penelitian}

Metode artikel ini menggunakan pendekatan kualitatif, dengan menggunakan data sekunder. Data sekunder diperoleh dengan menggunakan pendekatan library research, yaitu dengan melakukan penelusuran berbagai referensi yang mengkaji tentang kebijakan fiscal pada masa Khalifah Umar bin Khattab yang berupa buku, hasil penelitian, data website, dan sumber lainnya yang relevan dengan kajian ini. Teknik

7 Abdurrahman Qadir, Zakat dalam dimensi mahdhah dan sosial (Jakarta: PT. Raja Grafindo Persada, 1998), hlm. 85. 
analisis data menggunakan pendekatan descriptive analysis, yaitu setelah data dikumpulkan kemudian dideskripsikan, kemudian dianalisis untuk memperoleh jawaban sesuai dengan tujuan artikel ini.

\section{Metode Penelitian}

Penelitian ini bersifat deskriptif kualitatif. Penelitian deskriptif adalah penelitian yang berusaha untuk mengutarakan pemecahan masalah yang ada berdasarkan data di lapangan. Jadi penelitian deskriptif menampilkan data, menganalisa dan menginterprestasikan, yang bertujuan guna memberi gambaran dan informasi yang akurat dari berbagai sumber serta untuk mendapatkan kesimpulan yang mendukung pembahasan. ${ }^{8}$ Penelitian dilaksanakan di Desa Lipursari Kecamatan Leksono Kabupaten Wonosobo. Guna memperoleh data yang akurat, penulis memakai metode pengumpulan data yaitu wawancara. Dalam penelitian ini terdapat dua sumber yaitu sumber data primer dan sumber data sekunder. Setelah terkumpulnya data-data maka penulis menganalisa dengan menggunakan metode deskriptif analisis dengan memakai pendekatan kualitatif.

\section{Hasil dan Pembahasan}

\section{Sekilas tentang Zakat Fitrah dan Dukun Bayi}

Secara etomologi zakat adalah suci, bersih atau tumbuh. Sedangkang secara terminologi syara' adalah mengeluarkan sebagian harta tertentu guna diberikan terhadap orang-orang yang berhak menerimanya dengan syarat-syarat yang telah ditentukan oleh syara'.

Zakat secara bahasa berasal dari kata " زكى - يزكى - الزكاة" yang artinya suci, berkah, tumbuh, dan terpuji. ${ }^{9}$ Dalam buku yang berjudul Pedoman Zakat, menurut bahasa zakat yaitu nam (kesuburan), barakah (keberkahan), thaharah (kesucian), dan

\footnotetext{
${ }^{8}$ Lexy J. Moleong, Metodologi Penelitian Kualitatif, Bandung: PT Remaja Rosdakarya, 2012, hlm 5. ${ }^{9}$ Ibnu Mansur, Lisan al-Arab, Jilid II, Beirut-Libanon: Dar Sader, 1990, hlm, 35
} 
juga tazkiyahtathar (mensucikan). ${ }^{10}$ Jika dilihat dari segi bahasa, zakat berasal dari kata zakat (yang berbentuk masdar), yang berarti: tumbuh, berkah, suci, bersih, dan baik. ${ }^{11}$ Jadi menurut bahasa zakat dapat diartikan bahwa harta yang dikeluarkan untuk zakat akan menjadi suci, tumbuh, terpuji, berkah, bertambah, subur, dan berkembang. ${ }^{12}$

Zakat menurut istilah adalah sebagian harta tertentu yang diharuskan Allah swt untuk diberikan kepada orang-orang yang berhak menerimanya dengan syarat-syarat tertentu. ${ }^{13}$ Dalam sebuah kitab Kifayah al- Akhyar, zakat merupakan sebagian harta tertentu yang diserahkan kepada orang-orang tertentu dan dengan syarat tertentu. ${ }^{14}$ Dalam kitab Fath al- Qarib, zakat merupakan suatu harta tertentu yang diberikan dengan cara-cara tertentu kemudian diberikan kepada golongan-golongan tertentu pula. ${ }^{15}$ Dalam sebuah kitab Fath al-Mu'in, zakat merupakan sesuatu harta yang dikeluarkan (diambil) dari sebagian harta atau badan dengan ketentuan tertentu. ${ }^{16}$

\section{Dukun bayi}

\section{a.Sejarah Dukun Bayi}

Sejak kapan dukun bayi mulai memiliki kedudukan? Kurang lebih sejak masa kolonial atau di masa penjajahan, yang mana suatu negara masih menguasai sumber daya negara lain. Pembatasan itu berlanjut hingga sekarang. Bermacam regulasi atau aturan negara sejak masa kolonial hingga paskareformasi nampak tidak akomodatif atau tidak dapat menyesuikan diri dengan keberadaan dukun bayi.

Pandangan negara yang menilai bahwa praktik medis tradisional tidak layak dan tidak kontekstual atau tidak sesuai dengan analisa perkembangan dunia medis modern, merupakan faktor yang dapat berpengaruh melahirkan kebijakan yang memarjinalkan

\footnotetext{
${ }^{10}$ Hasbi Ash-Shiddieqy, Pedoman Zakat, Jakarta: PT. BulanBintang, Cet. V, 1984, hlm. 24

${ }^{11}$ Asnaini, Zakat Produktif Dalam Prespektif Hukum Islam, Yogyakarta: Pustaka Pelajar, 2008, hlm. 23

12 Ubbadul Adzkiya', "HUBUNGAN ANTARA MODAL DENGAN PENERIMAAN DAN KEUNTUNGAN PEDAGANG MAKANAN DI SEKITAR MASJID AGUNG JAWA TENGAH" (Universitas Gadjah Mada, 2016), http://etd.repository.ugm.ac.id/home/detail_pencarian/97822.

${ }^{13}$ llyas Supena, Manajemen zakat, Semarang: Walisongo Press, 2009, hlm. 2

${ }^{14}$ Imam Taqi al-Din, Kifayah al-Akhyar, Beirut: Dar al-Kutub al-Ilmiyah, 1973, hlm. 386

${ }^{15}$ Syekh Muhammad Ibn Qasim al-Ghazzi, Fath al-Qarib al-Mujib, Dar al-Ihya al-Kitab, al-Arabiyah, Indonesia, tth, hlm. 158

${ }^{16}$ Syekh Zainuddin Ibn Abd Aziz al-Malibary, Fath al-Mu'in, Kairo: Maktabah Dar al- Turas, 1980, hlm. 50
} 
atau menyebabkan keterbatasan berkembangnya praktik dukun bayi yang berbeda dengan praktik medis modern.

Menurut Eric A. Stein yang dikutip oleh Miftahul Rohman dalam jurnal Sejarah Page | 105 Peminggiran Dukun Bayi, semenjak masa Pemerintahan Kolonial, dukun balita sudah ditatap negatif. Pada akhir abad ke- 19 Meter, seseorang perwira korp kedokteran militer bernama Dokter. H. Van Buuren sudah menjuluki dukun balita di Jawa selaku 'malaikat maut'. Cemoohan itu didasarkan pada pemikiran orang Belanda kalau aplikasi kedokteran atau medis tradisional yang dicoba dukun balita dinilai primitif serta membahayakan. Tidak hanya itu, mereka tidak memahami metode kedokteran modern yang baginya steril serta cocok dengan standar kedokteran internasional.

Walaupun demikian, upaya peminggiran dukun balita secara terstruktur baru terlihat di tahun 1930- an. Atas anjuran Yayasan Rockefeller, Dinas Kesehatan Warga Hindia- Belanda, mencanangkan pelatihan dukun balita yang mengacu pada standar kebersihan serta biomedis modern. Pelatihan itu wajib diiringi oleh dukun balita serta pula siapapun yang hendak jadi bidan.

Diklat kebidanan itu lumayan sukses serta mencirikan lahirnya bidan- bidan di Jawa. Seturut setelah itu, proyek kolonial itu diduplikasi Dinas Kesehatan Republik Indonesia pada masa pemerintahan Soekarno( 1950-65). Proyek itu pula dibesarkan lebih jauh di era Orde Baru. Di masa- masa seperti itu, pelatihan bidan sampai penyebarannya ke pelosok- pelosok tumbuh pesat. Intensivikasi persalinan oleh bidan serta pemasangan Implan BKKBN utamanya selaku bagian dari proyek pembangunan rezim Soeharto, ialah kebijakan yang pada kesimpulannya terus menjadi menyudutkan dukun balita.

Di kala itu, BKKBN mengharuskan diklat kepada tiap dukun balita. Upaya demikian digunakan buat menstandarisasi aplikasi persalinan serta pengendalian kelahiran yang sejalan dengan ilmu kedokteran modern. Metode pemotongan tali pusar sampai pijat perut sebagaimana yang sudah dipraktikan dukun balita secara turun- temurun dikira negeri selaku aktivitas malpraktik. Oleh karenanya, pelatihan serta sertifikasi perawat ataupun bidan diharuskan. Banyak dukun balita kala itu yang tidak menjajaki program tersebut, secara otomatis mereka dicap selaku 'dukun liar'.Di dalam suasana seperti itu peran dukun balita jadi inferior dalam kontestasinya dengan bidan desa.

Tidak hanya lebih terampil, bidan- bidan itu dinilai lebih cocok dengan orientasi agama warga kala itu yang sedang gencar- gencarnya ke arah arabisasi/ islamisasi. 
Memanglah tidak terdapat jaminan kalau seseorang bidan berdoa kala melaksanakan tugasnya, namun warga menyederhanakan kesalehan beragama dengan cuma mengacu pada pemakaian hijab. Dalam kurun waktu inilah, dukun- dukun balita yang semula tidak berjilbab dan dikira selaku kejawen/ tidak islami, berangsur- angsur merubah penampilannya. Bukan cuma itu saja, doa- doa islami semacam lafal basmalah, pula dirapal oleh dukun balita. Secara universal, penyesuaian- penyesuain itu dicoba supaya mereka senantiasa survive di warga.

Terlebih lagi bila kita membicarakan warga pedesaan yang masih kental dengan peninggalan tradisi, kedudukan dukun balita masih dikira signifikan. Semenjak balita dalam isi, bermacam pengobatan pijat serta bermacam racikan spesial diberikan supaya pertumbuhan bakal anak terus menjadi membaik. Belum lagi apabila memikirkan kosmologi Jawa menimpa slametan selaku ekspresi khas orang Jawa, upacara slametan pada bunda serta balita umumnya dipimpin dukun balita. Ritual semacam mitoni, mendem ari- ari, brokohan, sepasaran serta lainya, ialah serangkaian ritual pada balita yang biasanya dipandu ataupun cocok dengan instruksi dari dukun balita.

Dengan demikian, dukun balita ialah figur yang sangat berarti untuk warga pedesaan sebab kedudukannya tidak seluruhnya dapat diwakili bidan balita. Keahliannya di bidang kesehatan tradisional serta spiritualitas di satu sisi, membuat mereka lebih disegani. Inilah kondisi riil di warga tradisional. Sebaliknya dalam konteks nasional kita hari ini, pemerintah lewat Kemenkes sudah membuat kebijakan yang secara halus memforsir dukun balita senantiasa terletak di pinggiran. Walaupun sistem pemerintahan di Indonesia semenjak masa kolonial sampai hari ini sudah mensubordinasikan dukun balita, senantiasa saja kebutuhan warga terhadapnya masih senantiasa terdapat. Dukun balita masih eksis meski sesungguhnya tengah di ambang kepunahan lantaran arus modernitas. ${ }^{17}$

b. Pengertian Dukun Bayi

Dukun ataupun" orang pintar" merupakan suatu sebutan yang secara universal dimengerti dalam penafsiran orang yang mempunyai kelebihan dalam perihal keahlian supranatural yang menyebabkannya bisa menguasai perihal tidak kasatmata dan sanggup berbicara dengan arwah serta alam gaib, yang dipergunakan buat menolong

\footnotetext{
${ }^{17}$ Miftahul Rohman, Sejarah Peminggiran Dukun Bayi, https://ijir.iain-tulungagung.ac.id, diakses pada tanggal 3 februari 2021
} 
menuntaskan permasalahan di warga, semacam penyakit, kendala sihir, kehabisan benda, kesialan, serta lain- lain. ${ }^{18}$

Istilah dukun umumnya digunakan di pedesaan, sedangkan "orang pintar"

Page | 107 atau paranormal biasanya digunakan di antara populasi perkotaan. Dukun bayi ialah mereka yang memberi bantuan pada proses kelahiran atau dalam hal-hal yang berhubungan dengan bantuan persalinan. ${ }^{19}$

Dukun balita ataupun dukun beranak merupakan seseorang anggota warga, pada biasanya seseorang perempuan yang menemukan keyakinan dan mempunyai keahlian membantu persalinan secara tradisional serta mendapatkan keahlian tersebut dengan metode turun temurun belajar secara instan ataupun metode lain yang menjurus kearah kenaikan keahlian tersebut dan lewat petugas kesehatan. ${ }^{20}$

Dukun bayi yang dimaksud dalam skripsi ini bukanlah dukun yang biasa dikenal dengan dukun paranormal melain dukun yang khusus menangani proses kelahiran bayi dan merawat bayi dari mulai lahir hingga sampai puputan (putusnya tali pusar bayi tersebut). Karna keterampilan dukun bayi adalah sifatnya turun temurun menggunakan kecerdasan spiritual yang mana dapat membantu seseorang untuk mengembangan dirinya secara utuh dan menerapkan nilai positif. Sehingga kecerdasan spiritual yang berkembang dengan baik akan ditandai dengan kemampuan seseorang untuk bersikap mudah menyesuaikan diri dengan lingkungan, memiliki tingkat kesadaran yang tinggi dan mampu mengambil pelajaran yang berharga dari suatu kegagalan. sedangkan dukun paranormal menggunakan kekuatan yang berasal dari sumber gaib sebagai cara terpenting maupun sebagai cara alternatif untuk mencapai keinginan dan tujuan pribadi secara seketika.

\section{c. Eksistensi Dukun Bayi}

Keberadaan dukun pengobat serta aplikasi penyembuhan tradisional nyatanya masih eksis di tengah penyembuhan modern. Eksistensi mereka masih diakui oleh warga selaku penggunanya. Bermacam tipe dukun antara lain, 1) dukun pijat yang

\footnotetext{
${ }^{18}$ Sartini, Sartini; Ahimsa-Putra, Heddy Shri (2017-02-27). "Redefining The Term of Dukun"

${ }^{19}$ Rina Anggorodi, Dukun Bayi Dalam Persalinan Oleh Masyarakat Indonesia, Makarya, kesehatan, VOL. 13, NO. 1, JUNI 2009: 9-14, hlm. 10

${ }^{20}$ http://jurnalbidandiah.blogspot.com/2012/06/pembinaan-dukun-bayi-di-komunitas.html. Diakses pada kamis 10 Sep. 20.
} 
bekerja buat mengobati penyakit yang diakibatkan sebab kurang berfungsinya uraturat serta aliran darah, 2) dukun Sangkal Putung yang menyembuhkan penderita patah tulang, 3) dukun Petungan yang berikan nasihat berbentuk perhitungan hari baik bagi Weton( kitab primbon), 4) dukun yang pandai menyembuhkan gigitan ular berbisa serta fauna buas, 5) dukun balita ialah dukun yang membagikan pertolongan pada waktu serta sehabis persalinan, serta 6) dukun Perewangan ialah dukun yang dikira mempunyai kemamuan magis sehingga bisa membagikan penyembuhan ataupun nasihat yang berhubungan dengan alam gaib.

Selaku contoh eksistensi dukun dalam masa penyembuhan modern di Indonesia bisa kita amati dari Hasil Studi Kesehatan Dasar tahun 2007 yang menampilkan persentase yang besar dalam pemanfaatan dukun buat membantu persalinan. Tabel di dasar ini menampilkan 5 provinsi dengan tingkatan pemanfaatan tenaga dukun persalinan paling tinggi di Indonesia. Maluku Utara yang menduduki posisi awal menampilkan sebanyak 56,7\% persalinan anak awal serta 55, $1 \%$ persalinan anak terakhirnya ditolong oleh dukun. Dari tabel di atas nampak kalau tingkatan keyakinan warga terhadap dukun dalam membantu persalinan masih besar paling utama di wilayah pedesaan. Perihal ini pula menampilkan kalau keberadaan dukun serta gunanya selaku pengobat masih menempel dalam keseharian warga Indonesia. ${ }^{21}$

\section{Praktik Pelaksanaan Zakat Fitrah kepad Dukun Bayi di Desa Lipursari Kecamatan Leksono Kabupaten Wonosobo}

Zakat adalah kewajiban bagi setiap muslim. Seperti yang telah dipaparkan sebelumnya kalau mayoritas penduduk di Desa Lipursari pemeluk agama Islam yang senantiasa taat terhadap ajaran-ajaran agama Islam, dalam permasalahan ibadah salah satunya yaitu zakat fitrah, penduduk Desa Lipursari senantiasa melaksanakannya. Masyarakat desa Lipursari merupakan termasuk masyarakat yang taat terhadap perintah agama.

Dengan itu penduduk desa Lipursari senantiasa taat melakukan perintah agama baik dalam ibadah ataupun kegiatan-kegiatan yang bernuansa Islami salah satunya

\footnotetext{
${ }^{21}$ Irfan Ardani, Eksistensi Dukun dalam Era Dokter Spesialis, Jurnal Kajian Budaya Vol. 2 no. | 1 Juli 2013, hlm. 24-25
} 
yaitu kewajiban mengeluarkan zakat fitrah. Kesadaran penduduk desa Lipursari mengenai kewajiban membayar zakat fitrah relatif tinggi, karena sudah menjadi adatistiadat atau kebiasaan di setiap akhir bulan suci ramadhan sampai hari raya idul fitri. Di desa Lipursari identik dengan mengeluarkan zakat fitrah. Sehingga tidak mereka sadari bahwa mereka menyambut tibanya hari raya Idul Fitri dengan mengeluarkan zakat fitrah.

Namun dalam kasus skripsi ini yang terjadi di lapangan adalah pembayaran zakat fitrah kepada dukun bayi. Pembayaran zakat fitrah tersebut langsung diberikan kepada dukun bayi tanpa melalui amil zakat terlebih dahulu. Hal semacam itu sudah menjadi kebiasaan masyarakat desa Lipursari dari nenek moyang dulu sampai sekarang masih dilakukan. Karna itu adalah salah satu sebuah adat istiadat yang sudah berlaku sejak dahulu sampai sekarang di desa Lipursari.22

Dalam permasalahan ini penulis mewawancarai beberapa masyarakat yang diantaranya adalah ibu Lilis, yang mengatakan bahwa dia selalu mengeluarkan zakat fitrah setiap malam hari raya Idul Fitri. Dia menambahkan bahwa sebagian zakat fitrah anaknya yang masih kecil yang berumur dua tahun kebawah diberikan kepada dukun bayi secara langsung tanpa melalui amil zakat. Dengan alasan dukun bayi tersebut telah membantu proses persalinan dan ikut serta merawat bayi tersebut. ${ }^{23}$

Begitupun dengan ibu Erni, juga mengatakan bahwasanya dia juga salah satu masyarakat yang mengeluarkan zakat fitrah untuk anaknya yang masih berumur dua tahun kebawah kepada dukun bayi. Sedangkan zakat fitrahnya ibu Erni sendiri diberikan kepada panitia zakat yang sudah tersedia di masjid ataupun mushola. Zakat yang diberikan kepada dukun bayi biasanya berupa nominal uang sedangkan zakat fitrah yang diberikan kepada panitia zakat adalah berupa bahan pokok (beras). ${ }^{24}$

Dari hasil wawancara yang peneliti lakukan terhadap pemberi zakat fitrah di Desa Lipursari dengan Ibu Erni dan Ibu Lilis disimpulkan bahwa praktik zakat fitrah yang dilakukan kepada dukun bayi itu berlaku untuk bayi yang dibawah 2 tahun atau masih

\footnotetext{
${ }^{22}$ Bapak Wagiman, wawancara, 30 Oktober 2020

${ }^{23}$ Ibu Lilis, wawancara, tanggal 1 November 2020

${ }^{24}$ Ibu Erni, wawancara, tanggal 1 November 2020
} 
dalam pengasuhan dukun bayi. Sehingga zakat fitrah bayi tersebut diberikan kepada dukun bayi dalam bentuk materi ataupun nominal, sekitar Rp. 30.000 (setara dengan harga 2,5 kg beras untuk Zakat Fitrah). Dan ketentuan itu dilakukan di Desa Lipursari sejak dulu hingga sekarang.

Dari hasil wawancara yang dilakukan oleh dukun bayi bernama Mbah Sodri, mengatakan bahwa praktik zakat fitrah di Desa Lipursari memang ada dan tidak melalui paksaan terhadap muzaki atau pemberi zakat, biasanya zakat yang diterima oleh dukun bayi dari pemberi zakat, yaitu perorangan (bayi) sebesar Rp. 30.000 atau setara dengan harga beras 2,5 kg. Disisi lain dukun bayi juga menerima pembagian zakat fitrah dari masjid di Desa Lipursari. ${ }^{25}$

Begitupun wawancara yang dilakukan oleh Mbah Sunhaji, mengatakan bahwa praktik zakat fitrah di Desa Lipursari tidak diwajibkan diberikan kepada dukun bayi, namun pemberian zakat kepada dukun bayi dilakukan sebagai tanda terimakasih terhadap bayi yang telah diasuhnya selama 2 tahun. Praktik zakat fitrah kepada dukun bayi di Desa Lipursari memang ada, dan biasanya zakat yang diterima oleh dukun bayi dari pemberi zakat, yaitu perorangan (bayi) sebesar Rp. 30.000 atau setara dengan harga beras $2,5 \mathrm{~kg}^{26}$

Berdasarkan hasil wawancara yang peneliti lakukan terhadap dukun bayi di Desa Lipursari yaitu Mbah Sodri dan Mbah Sunhaji disimpulkan bahwa zakat fitrah yang dilakukan dari pemberi zakat dan penerima zakat memang benar ada, dan dukun bayi menerima zakat tersebut setiap tahunnya, zakat yang diterima jika ditotal sebesar 500.000 sampai dengan 2.000.000,-. Zakat yang diterima dukun bayi adalah zakat yang diperoleh dari bayi yang diasuhnya selama 2 tahun di Desa Lipursari.

Akan tetapi dalam pemberian zakat fitrah kepada dukun bayi tidak melalui paksaan, yang mana bila tidak memberi zakat fitrah ke dukun bayi, maka tidak masalah atau tidak memberatkan. Dari dukun bayi juga tidak memasang tarif dengan target nominal, dan sebagai bentuk kewajiban umat muslim mengeluarkan zakat fitrah.

\footnotetext{
${ }^{25}$ Ibu Sodri, wawancara, tanggal 3 November 2020

${ }^{26}$ Ibu Sunhaji, wawancara, tanggal 3 November 2020
} 
Namun hal itu dilakukan oleh pemberi zakat kepada dukun bayi sebagai salah satu bentuk tanda terimakasih.

\section{Pandangan Hukum Islam Terhadap Pendistribusian Zakat Fitrah Kepada Dukun Bayi di Desa Lipursari Kecamatan Leksono Kabupaten Wonosobo}

Pandang hukum Islam terhadap pendistribusian zakat fitrah itu diberikan kepada siapa saja golongan-golongan tertentu yang sudah dijelaskan sebagaimana di AlQur'an Surat At-Taubah ayat 60 sebagai berikut:

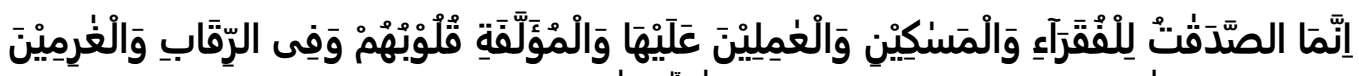

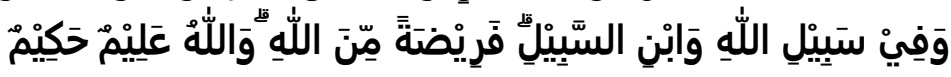

Artinya: "Sesungguhnya Zakat- Zakat itu, hanyalah untuk orang-orang fakir, orang-orang miskin, penguruspengurus Zakat, Para mu'allaf yang dibujuk hatinya, untuk (memerdekakan) budak, orangorang yang berhutang, untuk jalan Allah dan untuk mereka yuang sedang dalam perjalanan, sebagai suatu ketetapan yang diwajibkan Allah, dan Allah Maha mengetahui lagi Maha Bijaksana. ${ }^{27}$

Maksud dari ayat diatas bahwa orang yang berhak dan yang diutamakan diberi zakat fitrah adalah seorang fakir dan miskin. Ketika semua fakir dan miskin sudah mendapatkan bagian secara merata, baru dibagikan kepada golongan-golongan lainnya. Menurut pendapat Yusuf Qardawi bahwa kesepakatan para ulama zakat fitrah hanya diberikan terhadap fakir dan miskin yang memeluk bergama Islam. Yusuf Qardawi menambahi dikhususkannya zakat fitrah itu diberikan kepada orang fakir dan miskin muslim, karena mereka sejalan pada ajaran Rasulullah supaya orang muslim dapat menolong saudara muslim lainnya yang kurang mampu pada hari raya Idul Fitri. Rasulullah s.a.w bersabda: "Cukupkanlah mereka (kaum fakir miskin) pada hari itu (idul fitri)". 28

${ }^{27}$ Qur'an Kemenag in MS Word, 2010

${ }^{28}$ Yusuf Qordawi, Hukum Zakat, Jakarta: Litera Antar Nusa, 1997. hlm. 963 
Adapun kendala-kendala dalam penyaluran pendistribusian zakat fitrah kepada dukun bayi adalah sebagai berikut Dukun bayi yang profesinya sudah lama dan bisa menjangkau banyaknya konsumen berpotensi mendapatkan penghasilan keseluruhan diatas rata-rata Upah menengah kabupaten (UMK) tetapi dia masih mendapatkan bagian zakat fitrah secara merata. Dilihat dari pandangan hukum Islam seharusnya praktek tersebut tidak diperbolehkan untuk dilakukan / seharusnya tidak menerima zakat tersebut. Karena dia sudah termasuk orang yang mampu.

Sedangkan dukun bayi yang profesinya belum lama dan masih terjangkau konsumennya yang penghasilannya masih dibawah rata-rata (UMK). Maka dukun bayi seperti inilah yang berhak diberi zakat fitrah. Karna dukun bayi ini masih tergolong orang yang miskin atau belum mampu.

\section{Analisis Praktik Pendistribusian Zakat Fitrah Kepada Dukun Bayi di Desa Lipursari}

Pembahasah di atas sudah dijelaskan pelaksanaan praktik pendistribusian zakat fitrah kepada dukun bayi di Desa Lipursari Kecamatan Leksono Kabupaten Wonosobo bahwa dari hasil observasi dan wawancara dengan masyarakat dan dukun bayi di Desa lipursari khususnya di tiga dusun yang menjadi obyek utama dalam penelitian yakni di dusun Dampit, Pasunten, dan Bringin mengenai sistematika atau alur dari pendistribusian zakat fitrah masih bersifat tradisional yaitu diberikan secara langsung kepada penerima zakat (dukun bayi) tanpa melalui perantara atau panitia zakat, penulis mendapatkan gambaran yang cukup jelas bagaimana praktik pendistribusian zakat fitrah kepada dukun bayi.

Dalam praktik pendistribusian zakat fitrah kepada dukun bayi sudah menjadi kebiasaan di Desa Lipursari Kecamatan Leksono Kabupaten Wonosobo. Praktik zakat fitrah kepada dukun bayi diberikan secara langsung dari pemberi oleh penerima, yang mana zakat fitrah tersebut diterima dari bayi yang diasuhnya selama 2 tahun. Namun dalam pemberian zakat fitrah kepada dukun bayi tidak melalui paksaan, tetapi zakat fitrah yang diberikan kepada dukun bayi adalah sebagai tanda terima kasih atas bayi yang diasuhnya di Desa Lipursari. 
Praktik pendistribusian zakat fitrah kepada dukun bayi sudah ada sejak dulu hingga sekarang, hal tersebut dikarenakan adanya adat istiadat yang berlaku di Desa Lipursari Kecamatan Leksono Kabupaten Wonosobo. Dalam praktiknya, zakat fitrah kepada dukun bayi didapat dari bayi yang usianya kurang dari 2 tahun atau masih dalam masa pengasuhan. Pemberian zakat fitrah kepada dukun bayi tidak hanya didapatkan dari bayi yang telah diasuhnya, melainkan juga didapat dari masjid yang ada di Desa Lipursari.

Sehingga dari hasil wawancara yang peneliti lakukan terhadap pemberi zakat fitrah di Desa Lipursari dengan Ibu Erni dan Ibu Lilis disimpulkan bahwa praktik zakat fitrah yang dilakukan kepada dukun bayi itu berlaku untuk bayi yang dibawah 2 tahun atau masih dalam pengasuhan dukun bayi. Sehingga zakat fitrah bayi tersebut diberikan kepada dukun bayi dalam bentuk materi ataupun nominal, sekitar Rp. 30.000 (setara dengan harga 2,5 kg beras untuk Zakat Fitrah).

\section{Analisis Pandangan Hukum Islam Terhadap Praktik Pendistribusian Zakat Fitrah Kepada Dukun Bayi di Desa Lipursari}

Zakat dalam pandangan hukum islam merupakan tali pengikat atau sarana yang erat dalam mengikat hubungan vertikal antara manusia dengan Allah serta hubungan horizontal antara manusiadengan manusia, khususnya antara yang mampu dan tidak mampu (miskin), dan saling memberi kemanfaatan baik berupa moril maupun materil, baik dari penerima (mustahik) maupun dari pemberi (muzzaki).

Sebagaimana dipaparkan pada bab sebelumnya, bahwa pendistribusian Zakat Fitrah yang lebih diutamakan yaitu orang miskin, jika golongan orang miskin sudah terbagi dengan rata semua, maka Zakat Fitrah yang masih tersedia baru diberikan kepada golongan para mustahiq atau orang-orang yang berhak menerima Zakat sesuai dengan yang di terangkan pada Al-Qur'an surat At-Taubah ayat 60 .

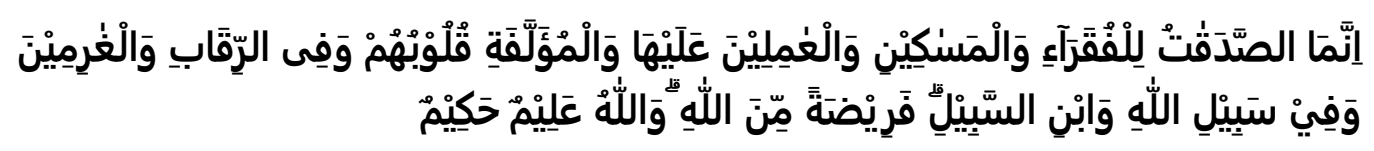

JURNAL IQTISAD: Reconstruction of Justice and Welfare for Indonesia - Vol. 8 No. 1 (2021) 
Artinya: "Sesungguhnya Zakat- Zakat itu, hanyalah untuk orang-orang fakir, orang-orang miskin, penguruspengurus Zakat, Para mu'allaf yang dibujuk hatinya, untuk (memerdekakan) budak, orangorang yang berhutang, untuk jalan Allah dan untuk mereka yuang sedang dalam perjalanan, sebagai suatu ketetapan yang diwajibkan Allah, dan Allah Maha mengetahui lagi Maha Bijaksana. ${ }^{29}$

Pada ayat diatas telah dijelaskan yang berhak menerima Zakat adalah sebagai berikut:

1. Orang fakir adalah orang yang sengsara hidupnya, tidak mempunyai harta benda dan kekuatan tenaga guna memenuhi penghidupannya.

2. Orang miskin adalah orang yang tidak bisa mencukupi kehidupannya serta dalam Keadaan kekurangan.

3. Pengurus Zakat adalah orang yang diberi amanat untuk mengumpulkan serta membagikan Zakat.

4. Muallaf adalah orang kafir yang ada kemungkinan akan masuk Islam serta orang yang baru masuk ke dalam Islam yang imannya masih belum kuat.

5. Memerdekakan budak: mencakup juga untuk melepaskan Muslim yang ditawan oleh orang-orang kafir.

6. Orang berhutang adalah orang yang berhutang dan hutangnya untuk kepentingan yang bukan maksiat dan tidak sanggup untuk membayarnya.

7. Pada jalan Allah (fisabilillah): ialah buat keperluan pertahanan Islam serta kalangan Muslimin. Di antara mufasirin terdapat yang berkomentar kalau Fi sabilillah itu cuma mencakup dalam peperangan serta pula terdapat yang berkomentar mencakup kepentingan- kepentingan universal semacam mendirikan sekolah, rumah sakit serta lain- lain.

8. Orang yang sedang berjalanan dijalan Allah swt yang bukan maksiat serta mengalami kesulitan dalam perjalanannya.

Bersumber pada ayat di atas, kalau pendistribusian Zakat Fitrah ataupun pembagian Zakat itu wajib disalurkan kepada para mustahiq( orang yang berhak menerimanya) yang jumlahnya terdapat 8 kalangan tersebut. Sebaliknya kalangan yang lain tidak berhak buat menerimanya. Tidak hanya itu, tujuan utama penyaluran Zakat Fitrah sebagaimana yang diperintahkan oleh Nabi Muhammad S. A. W. merupakan

${ }^{29}$ Qur'an Kemenag in MS Word, 2010 
buat orang miskin dalam wujud santapan pokok, semacam kurma serta gandum. Ada pula di Indonesia santapan pokoknya merupakan semacam beras.

\section{Analisis kendala pendistribusian zakat fitrah}

Berdasarkan pendapat penulis ketika dilihat dari segi ekonomi penghasilan dukun bayi tidak pasti ataupun tidak menentu. Karena dukun bayi ketika memijat ataupun mengasuh bayi tidak menentukan harga (seiklasnya) karena wilayah desa lipursari masyarakatnya sebagian besar sebagai petani. hal ini sesuai letak geografis Desa Lipursari terletak pada garis bujur 10.986.505 dan pada garis lintang -7.435.677.

Desa ini terletak pada ketinggian $550 \mathrm{~m}$ di atas permukaan laut.Desa Lipursari terletak di sebelah barat kota kabupaten Wonosobo ${ }^{30}$ dengan mayoritas penduduk di Desa Lipursari adalah seorang petani, Sehingga masyarakat belum bisa memenuhi kebutuhan hidup ekonomi di desa tersebut. Karena panennya seorang petani kurang lebih 3 bulan baru panen.

Sebagian besar warga di posisi riset memiliki mata pencaharian selaku petani, yang cuma mengandalkan pertanian selaku sumber kehidupan mereka. Dalam penuhi kebutuhan hidup mereka tiap hari, umumnya warga hendak menjual sebagian hasil pertaniannya semacam beras ke pasar. Hasil pertanian yang mereka peroleh cenderung dimanfaatkan buat kebutuhan hidup tiap hari. Pemasukan yang relatif terbatas, menyebabkan warga kesusahan kala wajib menghasilkan bayaran yang lumayan besar buat persalinan. Keadaan ini membuat warga kesimpulannya lebih banyak memilah pelayanan kesehatan yang relatif tidak memerlukan bayaran besar dalam waktu bertepatan, ialah tenaga dukun balita. Hasil wawancara dengan informan dikenal kalau persalinan dengan tenaga bidan dapat menghabiskan bayaran hingga Rp800. 000,terlebih jika posisi bidan yang relatif jauh. Ini berbeda apabila persalinan dicoba kepada dukun balita yang cuma menghasilkan bayaran antara Rp50. 000,- hingga dengan Rp100. 000,-. Untuk warga yang kurang sanggup bisanya membagikan beras sebanyak satu ataupun 2 sha'.

warga melaporkan kalau pendekatan tenaga kesehatan kepada warga masih dikira kurang serta butuh kenaikan. Sedangkan itu, pemikiran warga terhadap pelayanan yang diberikan oleh dukun balita lebih bertabiat kekeluargaan. Ikatan dukun balita dengan warga telah terbina dengan baik. Dukun balita dapat menenangkan

\footnotetext{
${ }^{30}$ https://lipursari-leksono.wonosobokab.go.id, diakses pada tanggal 3 februari 2021
} 
bunda berbadan dua serta membagikan pelayanan yang baik dan bertabiat kekeluargaan, serta pembayarannya relative murah tidak terdapat tarifnya. Dalam perihal ini umumnya dukun balita diberikan imbalan berbentuk beras sebanyak satu ataupun 2 sha'. Untuk mereka yang ekonominya relatif lumayan baik cenderung meningkatkan duit kurang lebih sebesar Rp50. 000,-. Berikutnya sebagian warga lebih mempercayai dukun sebab telah berpengalaman, serta telah banyak bunda yang dibantu melahirkan.

Terlepas dari itu, SDM masyarakat desa Lipursari juga rendah, yang mana sumber daya manusia memegang peranan penting dalam pembangunan. Serta letak geografis desa Lipursari terletak pada garis bujur 10.986.505 dan pada garis lintang -7.435.677. Sehingga SDM rendah di desa Lipursari ini juga terjadi karena faktor yang berasal dari lingkungan sekitar tempat tinggal dan kebiasaan yang diajarkan orangtua sangat menentukan kualitas masyarakat tersebut.

Oleh karena itu, sumber daya manusia di desa Lipursari yang rendah juga berdampak cukup signifikan terhadap timbulnya masalah lain, seperti perkembangan IPTEK yang lamban dan yang paling utama adalah tingkat pengangguran yang cukup tinggi di desa Lipursari kecamatan Leksono kabupaten Wonosobo serta dari rendahnya SDM tersebut, sebagian besar masyarakat di desa Lipursari kecamatan Leksono kabupaten Wonosobo adalah petani.

\section{Simpulan}

Berdasarkan hasil analisis dari penelitian yang dilakukan di Desa Lipursari yaitu tentang praktik pendistribusian zakat fitrah kepada dukun bayi, disimpulkan sebagai berikut; pertama, Praktik Zakat Fitrah kepada dukun bayi yang ada di desa Lipursari kecamatan Leksono kabupaten Wonosobo belum sesuai dengan Undang-undang No. 23 tahun 2011 tentang Pengelolaan Pendistribusian Zakat Fitrah kepada dukun bayi di desa Lipursasri. Karena zakat fitrah tersebut diberikan kepada dukun bayi tanpa melalui amil terlebih dahulu. Namun pendistribusian zakat fitrah diperbolehkan, hal itu dikarenakan salah satu adat istiadat yang berjalan atau dilakukan oleh masyarakat di desa Lipursari kecamatan Leksono kabupaten Wonosobo sudah ada sejak dulu dan turun temurun.

Kedua, dukun bayi di desa Lipursari kecamatan Leksono kabupaten Wonosobo termasuk dalam golongan orang yang berhak mendapatkan zakat fitrah, yang mana zakat fitrah wajib diberikan kepada dukun bayi. Karena dukun bayi termasuk kategori 
orang miskin, seperti yang telah dijelaskan oleh Nabi Muhammad Shallallahu alaihi wasalam dan menurut para ulama bahwa zakat fitrah diberikan kepada fakir dan miskin, karena fakir dan miskin lebih membutuhkan daripada 8 asnaf lainnya. Sehingga dukun bayi berhak mendapatkan zakat fitrah tersebut. Ketiga, kendala pendistribusian zakat fitrah kepada dukun bayi dari segi ekonomi yaitu penghasilan dukun bayi tersebut yang tidak pasti atau tidak menentu. Hal ini dikarenakan masyarakat di desa Lipursasi sebagian besar sebagai petani, sehingga dukun bayi tidak memberatkan masyarakat setempat untuk memberi upah dalam jumlah besar, karena pada dasarnya dukun bayi berprinsip ta'awun atau tolong menolong untuk kesejahteraan bersama.

\section{Daftar Pustaka}

Adzkiya', Ubbadul. Etika Bisnis Nabi Muhammad SAW: Sejarah, Ajaran Dan Praktik. Penerbit Lawwana, 2021. https://books.google.co.id/books?id=M7sxEAAAQBAJ.

—. "HUBUNGAN ANTARA MODAL DENGAN PENERIMAAN DAN KEUNTUNGAN PEDAGANG MAKANAN DI SEKITAR MASJID AGUNG JAWA TENGAH." Universitas Gadjah Mada, 2016.

http://etd.repository.ugm.ac.id/home/detail_pencarian/97822.

Syuhud, Hafidz, and Islamic Law. "Interrelation of Mind and Revelation: Analysis of the Thought of Ulama Mutakallimin in the Formation of Islamic Law Interelasi Akal Dan Wahyu: Analisis Pemikiran Ulama Mutakallimin Dalam Pembentukan Hukum Islam" 2, no. 1 (2021): 43-61. https://doi.org/10.24260/jil.v.

Aziz, Abdul Muhammad Azzam dan Abdul Wahhab Sayyed Hawwas, Fiqh Ibadah, Terj. Kamran As'ad Irsyady, dkk, Jakarta: PT Kalola Printing, Cet. IV, 2015.

Qhadir, Abdurrachman Zakat: Dalam Dimensi Mahdhah dan Sosial, Jakarta: PT. Raja Grafindo Persada, 2001.

Bakar, Abu Jabir Al-Jazairi, Ensiklopedi Muslim, Jakarta: Darul Falah, 2015.

Abu Dawud, Ensiklopedia,

Kamal, Abu Malik Ibn Sayyid Salim, Fikih Sunnah Wanita, Terj. Firdaus, Jakarta: Qisthi Press, Cet. 2, 2014,

Al-Bukhari, Ensiklopedia. 
Al-Qur'an Terjemah Kemenag RI, 2002.

Asnaini, Zakat Produktif Dalam Prespektif Hukum Islam, Yogyakarta: Pustaka Pelajar, 2008,

Ayyub, Fikih.,

Azzam dan Hawwas, Fiqh,

Muhammad, B. Ali, Ensiklopedia Rukun Islam Seri Syahadat, Surakarta: PT. Borobudur Inspira Nusantara, 2013,

Bapak Wagiman, wawancara, 30 Oktober 2020

Darul Fikri.sch.id/mutiara-hadits-keutamaan-zakat-fitrah/. Diakses pada kamis, 10 September 2020.

Darul Fikri.sch.id/mutiara-hadits-keutamaan-zakat-fitrah/. Diakses Selasa, 08 September 2020.

Iriyani, Eva, Hukum Islam, Demokrasi Dan Hak Asasi Manusia, JURNAL ILMIAH, Volume 17 (2), 2017,

Aziz, Fikro Shulkhu, Analisis Pendistribusian Zakat Fitrah Menurut Imam Syafi'I, (Skripsi), Semarang. Fakultas Syari'ah dan Hukum Universitas Islam Negeri Walisongo Semarang, 2018,

Ash-Shiddieqy, Hasbi, Pedoman Zakat, Jakarta: PT. BulanBintang, Cet. V, 1984.

Hasbiyallah, Fikih Madrasah Tsanawiyah, Bandung: PT. Grafindo Media Pratama, 2006.

Kurnia, Hikmat dan Ade Hidayat, Panduan Pintar Zakat, Jakarta: Qultum Media, 2008.

https://lipursari-leksono.wonosobokab.go.id, diakses pada tanggal 3 februari 2021 